\title{
Dossiê
}

Partidos políticos, eleições e comportamento político-eleitoral no Brasil

\section{Incentivos para a fragmentação e a nacionalização do sistema partidário a partir do horário eleitoral gratuito no Brasil}

\author{
Bruno Wilhelm Speck \\ Professor da Universidade de São Paulo (USP) \\ Mauro Macedo Campos \\ Professor da Universidade Estadual do Norte Fluminense \\ Darcy Ribeiro (UENF).
}

\begin{abstract}
Resumo: $\mathrm{O}$ artigo analisa a relevância e o impacto do horário de propaganda gratuita sobre o sistema partidário no Brasil. Mostramos inicialmente porque a propaganda em rádio e TV é um recurso importante para os partidos políticos. Rádios e TVs abertas têm grande capilaridade na sociedade brasileira e são canais importantes de comunicação para alcançar o cidadão. A partir de uma breve retrospectiva sobre as regras a respeito do horário gratuito após a redemocratização, mostramos que a instituição da propaganda política gratuita, que tem uma longa tradição no Brasil, é hoje um recurso central na disputa política. Para precificar este espaço gratuito recorremos a cálculos a partir do mercado publicitário. Depois argumentamos que a forma de acesso e distribuição dos recursos midiáticos contribui tanto para o elevado número de partidos como também para a nacionalização do sistema partidário no país. A distribuição do horário eleitoral favorece os partidos pequenos em relação aos grandes. A uniformidade da alocação do tempo em todos os pleitos e circunscrições leva pequenas siglas a buscarem a nacionalização e freia o crescimento desproporcional de partidos em regiões específicas. $\mathrm{O}$ artigo conclui questionando a validade da teoria da cartelização partidária para o caso brasileiro.
\end{abstract}

Palavras chave: Brasil; Eleições; Sistema partidário; Horário Político Gratuito; Fragmentação; Nacionalização; Partido cartel.

Abstract: This text analyzes the impact of free airtime on the Brazilian party system. We argue airtime is an important resource in political competition in Brazil. We sustain radio and TV are key channels for political communication due to their capacity to reach out to virtually every citizen in contemporary Brazil and briefly summarize the history of regulating 
free airtime granted to political parties in Brazil. We suggest a method to estimate the value of free airtime based on market values for paid advertising for commercial TV ads. We then advance to our key argument. In addition to pointing out the important role of free airtime for political communication we argue the rules of allocating free airtime between parties are the key to understand how it impacts the party system. We hypothesize free airtime sets incentives for fragmenting the party system and nationalizing political parties in Brazil. First, the formula of distributing money between parties favors small parties and penalizes bigger parties. Second, the use of one same formula for all elections during four years sets incentives for parties to run at all levels and taxes regional party strongholds. The text ends questioning the validity of the cartel party hypothesis for the Brazilian case.

Keywords: Latin America; Brazil; Elections; Party systems; Free airtime; Fragmentation; Nationalization; Cartel Party.

\section{Introdução}

O argumento central deste artigo é que a modalidade de distribuição do horário de propaganda gratuita no Brasil cria incentivos para a fragmentação e a nacionalização do sistema partidário. O argumento é desenvolvido em dois passos. O primeiro passo se refere à relevância do horário gratuito em rádio e TV aberta, como recurso no proselitismo dos partidos políticos e na disputa eleitoral dos candidatos. Usamos como indicador a penetração destes dois meios de comunicação no Brasil desde os anos de 1960. Avaliamos o peso econômico da propaganda gratuita a partir da analogia com o mercado comercial. Com base nestes dois elementos (a capilaridade da TV e o seu peso no conjunto dos meios de comunicação de massa), concluímos que o horário de propaganda gratuita é um recurso central na disputa entre os partidos políticos. $\mathrm{O}$ segundo passo diz respeito aos critérios de distribuição do horário partidário e horário eleitoral entre os partidos políticos. Recapitulamos as mudanças das principais regras de alocação do horário político gratuito entre os partidos políticos desde o fim do governo militar. Ressaltamos a distribuição do tempo do horário político entre os partidos e a escolha da eleição para a Câmara dos Deputados como critério universal para a alocação proporcional do tempo em todas as eleições. Argumentamos que ambas as regras têm impacto específico sobre o sistema partidário no Brasil, fortalecendo partidos pequenos e promovendo a nacionalização destes nas diferentes circunscrições e eleições do país. Na seção final dialogamos com a tese sobre a cartelização do sistema partidário, originalmente formulada por Katz e Mair (1995), questionando a validade da tese para o caso brasileiro. 


\section{A importância do horário de propaganda gratuita na com- petição política}

Nesta seção será ressaltada a importância da mídia de rádio e TV aberta no que se refere ao desenvolvimento da democracia no Brasil. Em função da capilaridade que exercem em toda a sociedade, as informações transmitidas pela mídia eletrônica (rádio e televisão) têm forte influência sobre os cidadãos, seja em suas decisões de consumo, seja em suas atitudes e comportamentos políticos. A literatura especializada aponta que os meios de comunicação funcionam como um mecanismo redutor do custo de captação de informações por parte do eleitor sobre assuntos políticos, que são decisivos na hora do voto (Veiga, 2002; Borba, 2005). Nestes termos, autores como Marcus Figueiredo e Alessandra Aldé (2005) consideram que a propaganda eleitoral exerce três funções essenciais no processo competitivo: a condição que propicia ao partido (ou ao candidato) de reforçar no eleitor a intenção de voto; outra que se refere à capacidade de fazer o eleitor mudar de ideia e, assim, capturar votos de outro candidato concorrente; e, por fim, a função de convencimento dos eleitores indecisos.

A literatura também discute o tema dos meios de comunicação à luz de questões normativas ligadas à democracia representativa. Estas incluem a liberdade de realizar campanhas políticas e a competitividade do processo eleitoral (Dahl, 1972). Por um lado, os partidos necessitam de espaço para divulgar suas plataformas e programas eleitorais. Por outro, é também direito dos eleitores conhecerem as propostas e se informarem sobre estas, bem como sobre as opções partidárias e eleitorais apresentadas a cada período. Tanto o mercado (a propaganda partidária paga) como o acesso regulado (o horário gratuito alocado pelo Estado) podem criar desequilíbrios entre os partidos disputando a atenção e opinião dos eleitores. Nas democracias liberais partidos podem ser privados do acesso à comunicação via rádio e TV ou porque não dispõem de recursos suficientes, ou porque não cumprem determinados requisitos de acesso estabelecidos pela legislação.' Outro tema importante na literatura especializada se refere às consequências do papel crescente na propaganda televisiva para os custos das eleições (Gomes, 1994; Azevedo, 2006), para a dinâmica das campanhas e para o significado da representação

1 Para uma visão comparativa sobre diferentes modelos regulatórios sobre o acesso à mídia eletrônica ver Griner \& Arias (2007). 
nas democracias liberais (Manin, 1995). O nosso enfoque sobre o impacto da mídia na propaganda política parte do contexto brasileiro em que a lei veda a comercialização do espaço publicitário² e beneficia os partidos com tempo gratuito de rádio e TV.

\section{a) A capilaridade de rádio e TV aberta como meios de comunicação no Brasil}

Abordamos a questão da importância da mídia eletrônica para a disputa política em dois passos. Primeiro recuperamos dados sobre o histórico do grau de penetração de rádio e TV no território nacional. Depois buscamos por indicadores para precificar a propaganda política gratuita a partir de estimativas do custo da propaganda comercial. Em relação à primeira pergunta, podemos afirmar que a relevância de rádio e TV aberta para a dinâmica da disputa política no Brasil se deve à sua crescente penetração em todo o território nacional durante as últimas três décadas. O avanço tecnológico e o peso dos investimentos em redes de transmissão e estações sustentam a amplitude e a abrangência do sistema de telecomunicação no Brasil. A tabela 1 mostra a evolução histórica da capacidade de penetração dos meios de comunicação. Enquanto no início da transição democrática (1980) a TV teve uma cobertura de 56\% dos domicílios, a década da redemocratização (1982-1989) foi também o período de ampliação da cobertura de TV. Na média o crescimento foi de 2,4 pontos percentuais por ano, chegando a 80\% dos domicílios em 1991. Nas próximas duas décadas este crescimento foi mais moderado (0,8 pontos percentuais por ano), chegando a uma cobertura de $97 \%$ dos domicílios em 2010, cobrindo praticamente a totalidade do território nacional.

Tabela 1: Acesso dos domicílios particulares à rádio e televisão, 1960-2010

\begin{tabular}{|c|c|c|c|c|c|c|c|c|c|c|c|c|}
\hline \multicolumn{13}{|c|}{ Distribuição dos domicílios particulares permanentes segundo a existência de bens de consumo duráveis, Brasil 1960-2010 } \\
\hline \multirow{2}{*}{ Bens duráveis } & \multicolumn{2}{|c|}{1960} & \multicolumn{2}{|c|}{1970} & \multicolumn{2}{|c|}{1980} & \multicolumn{2}{|c|}{1991} & \multicolumn{2}{|c|}{2000} & \multicolumn{2}{|c|}{2010} \\
\hline & Abs & $\%$ & Abs & $\%$ & Abs & $\%$ & Abs & $\%$ & Abs & $\%$ & Abs & $\%$ \\
\hline Rádio & 3.912 .238 & 28,98 & 10.386 .763 & 58,92 & 19.203 .907 & 76,17 & 28.729 .548 & 82,69 & 39.107 .478 & 87,45 & 46.657 .714 & 81,4 \\
\hline Televisão & 601.552 & 4,46 & 4.250 .404 & 24,11 & 14.142 .924 & 56,10 & 27.650 .179 & 79,58 & 38.906 .707 & 87,00 & 54.473 .643 & 95,00 \\
\hline Geladeira & 1.479 .299 & 10,96 & 4.594 .920 & 26,06 & 12.697 .296 & 50,36 & 23.910 .037 & 68,82 & 37.202 .742 & 83,19 & 53.682 .457 & 93,70 \\
\hline Automóvel & & & 1.594 .465 & 9,04 & 4.809 .652 & 19,08 & 8.018 .457 & 23,08 & 14.604 .006 & 32,66 & 22.615 .377 & 39,50 \\
\hline Telefone & & & & & 3.182 .256 & 12,62 & 6.476 .056 & 18,64 & 17.774 .403 & 39,74 & & \\
\hline Maq. lavar roupa & & & & & & & 9.116 .375 & 26,24 & 14.799 .668 & 33,09 & 27.076 .707 & 47,20 \\
\hline Videocas sete & & & & & & & & & 15.787 .151 & 35,30 & & \\
\hline Microondas & & & & & & & & & 8.659 .309 & 19,36 & & \\
\hline Microcomputador & & & & & & & & & 4.748 .780 & 10,62 & 21.937 .198 & 38,30 \\
\hline Microcomputador - com acesso à internet & & & & & & & & & & & 17.596 .804 & 30,70 \\
\hline Ar-condicionado & & & & & & & & & 3.332 .643 & 7,45 & & \\
\hline Motocicleta para us o particular & & & & & & & & & & & 11.150 .013 & 19,50 \\
\hline Total de domicílios particulares permanente & S_Brasil_201 & & & & & & & & & & 57.315 .202 & \\
\hline
\end{tabular}

2 As restrições à compra de mídia eletrônica referem-se apenas aos veículos de radiodifusão. No caso da utilização de propaganda por internet (que são também veículos de mídia eletrônica), não existem tais impedimentos. Os candidatos podem pagar por esses serviços, contanto que cumpram as determinações do TSE, em cada eleição. 
A cobertura nacional da infraestrutura de TV não informa sobre o seu peso relativo em comparação com outros canais de comunicação, e principalmente sobre a sua relevância para a comunicação política. Em países onde a comercialização de espaço publicitário para propaganda política é liberada, o volume de recursos alocados pelos partidos para comprar tempo de rádio e TV é um forte indicador para precificar o peso deste recurso na disputa eleitoral. Nos Estados Unidos as campanhas presidências gastam mais da metade dos recursos em anúncios pagos na TV. ${ }^{3}$ Uma vez que a propaganda política paga nos veículos de radiodifusão é vedada pela legislação brasileira, devemos recorrer a outros indicadores para inferir qual a importância do horário de propaganda gratuita para a disputa política. Estudos empíricos a respeito do impacto do horário gratuito sobre os resultados eleitorais ainda são escassos. Os trabalhos existentes apontam para a importância da distribuição do tempo de propaganda política gratuita sobre os votos nas eleições majoritárias. ${ }^{4}$ A nossa estratégia é avaliar o valor do tempo do horário gratuito de propaganda política $(\mathrm{HG})$ recorrendo aos padrões de uso de diferentes canais de comunicação pelo mercado publicitário privado no Brasil. A alocação de recursos das empresas para a propaganda na mídia eletrônica será usada como indício pela importância destes meios de comunicação para informar e influenciar o consumidor. Argumentamos que esta precificação pelo mercado oferece uma pista importante para mensurar o valor do HG na comunicação política.

A distribuição dos recursos do mercado publicitário entre diferentes meios de comunicação no gráfico 1 ilustra o peso preponderante da TV no conjunto de canais de propaganda disponíveis. Dois terços dos recursos aplicados em publicidade e marketing são direcionados às televisões abertas. ${ }^{5}$ Com base nesta informação, apresentamos o nosso próximo cálculo, que precifica o valor do espaço ao HG nas tabelas de preço praticadas na publicidade na TV aberta. ${ }^{6}$ A concentração de anunciantes neste veículo de

3 Center for Responsive Politics, https://www.opensecrets.org/pres12/expenditures.php

4 Speck/Cervi $(2013,2014)$ analisam o impacto do horário sobre o voto a partir de regressões estatísticas, identificando um impacto significativo do horário eleitoral, do dinheiro do histórico de votação sobre os resultados eleitorais no primeiro turno das eleições municipais de 2012. Silveira/Mello (2011), aplicando um modelo semiexperimental às eleições para governador, chegam ao mesmo resultado.

5 Os dados brutos são disponibilizados na Pesquisa Anual de Serviços (PAS), que é realizada pelo IBGE, em que se demonstra uma estimativa da distribuição da receita por produto e atividade a cada ano.

6 Além do peso reduzido do espaço publicitário nas rádios, representando somente 3,5\% do volume total, a coleta da mesma informação sobre preços de anúncio praticados por milhares de estações de rádio em todo o território nacional tornaria a pesquisa inviável. 
comunicação justifica o procedimento no próximo passo, no qual limitamos à coleta de dados dos preços de mercado praticados nas TVs abertas.

Gráfico 1: Percentual de participação de diferentes meios de comunicação no mercado de publicidade em 2013

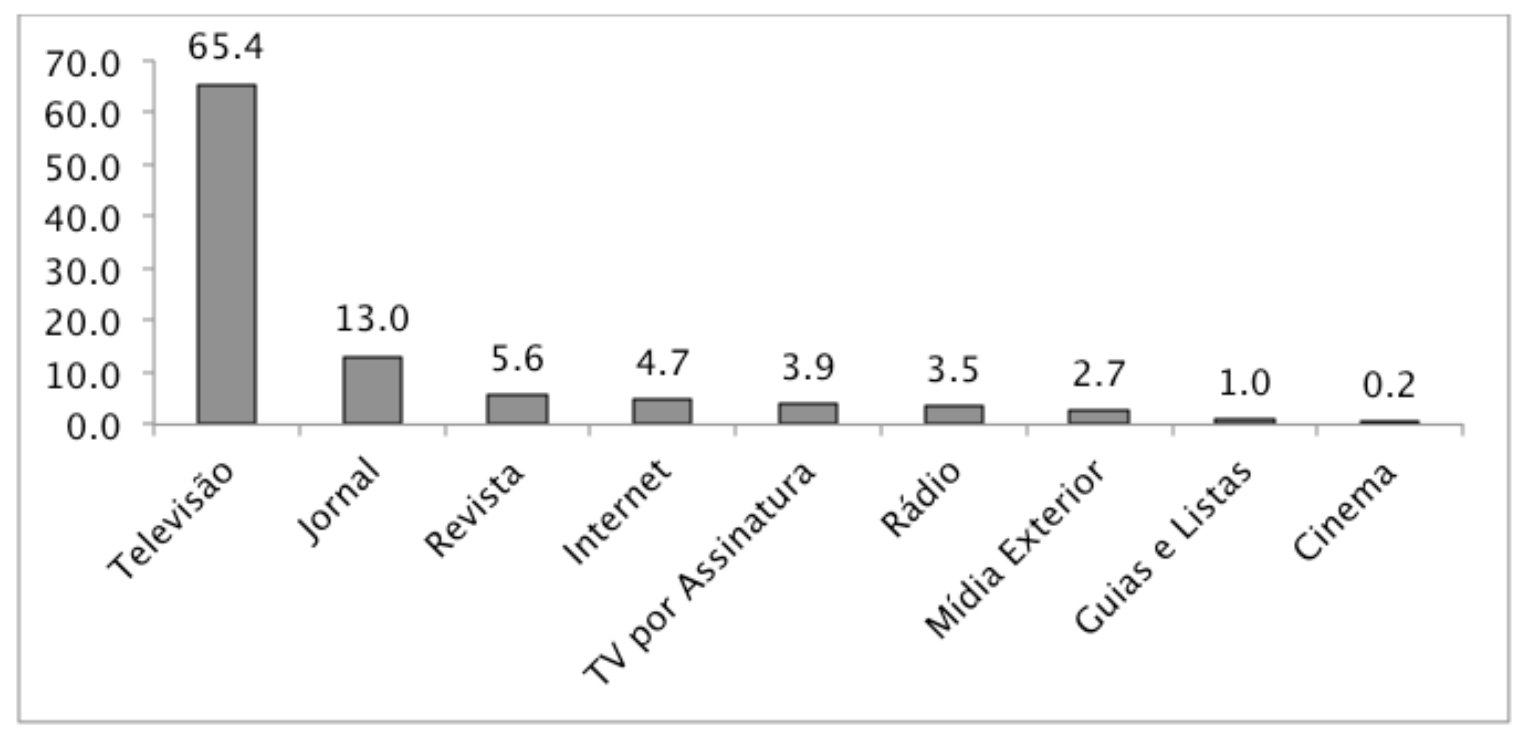

Fonte: Mídia Dados - Projeto Inter-Meios, 2013

\section{b) Precificando a propaganda gratuita}

Nesta seção aferimos o valor comercial deste espaço de propaganda política alocado aos partidos e candidatos no Brasil. Seguindo o exemplo de estudos anteriores (Speck, 2005; Campos, 2009, 2011), usamos como proxy para o benefício que o HG representa aos partidos e candidatos o valor comercial desses espaços midiáticos cedidos aos partidos políicicos. A pergunta que norteia o exercício é: Qual seria aproximadamente o preço cobrado pelas emissoras de televisão pelo HG, caso os partidos tivessem que arcar com esse custo? As estimativas referem-se às últimas eleições gerais de 2010 e às eleições municipais de 2012.

Antes de prosseguir com os cálculos sobre a monetarização dos espaços midiáticos, valem algumas considerações. Calculamos o valor comercial do tempo de rádio e TV separadamente para a propaganda partidária, em época não eleitoral, como também para as campanhas eleitorais. Incluímos no cálculo apenas as estações de TV aberta, não 
considerando as estações de rádio. Foram calculados os valores monetários tomando como base o tempo midiático médio.? Com base nessas definições, são considerados os resultados das últimas eleições gerais de 2010, que determinaram o rateio dos tempos de mídia para o decorrer da 54a legislatura, para o caso da propaganda eleitoral e para a propaganda partidária. A tabela 2 considera os valores praticados pelas cinco principais emissoras de televisão do país (Rede Globo, SBT, Record, Bandeirantes e Rede TV!) durante os horários de transmissão dos programas eleitorais gratuitos. ${ }^{8}$ Como indicado mais acima, o custo da propaganda nas estações de rádio está excluído deste cálculo. O gráfico 1 indica que este representa uma fração reduzida no mercado publicitário.

Os cálculos apresentados se baseiam em alguns pressupostos a respeito do comportamento dos partidos, das emissoras e dos telespectadores. Em relação aos partidos, o cálculo sugere que eles comprariam blocos diários de vários minutos em todas as emissoras (canais abertos) para informar o eleitor. A prática em outros países mostra que as inserções, quando pagas pelos partidos, são mais pontuais e mais dirigidas a públicos específicos, a partir dos horários de veiculação. Outra suposição é que as emissoras venderiam blocos ininterruptos de propaganda pelo valor cheio, quando na realidade poderíamos contar com desconto significativos nessas condições. A terceira suposição é que a propaganda eleitoral na TV aberta tem a mesma capacidade de chegar ao lar do eleitor quanto durante a programação normal. No entanto, a audiência durante a transmissão do HG cai significativamente, o que reduz o impacto do horário junto ao eleitor. ${ }^{9}$ Mesmo com as ressalvas acima, consideramos que a precificação do HG é um passo importante para objetivar as afirmações de que este representa um recurso importante na disputa política no Brasil.10

Para precificar o HG no Brasil, é necessário separar os seus principais componentes. O HG é composto pela propaganda durante a campanha eleitoral (HG-E) e a propaganda partidária, em períodos não eleitorais (HG-P). O nosso cálculo abrange um

7 A complexidade do mercado midiático se reflete nos preços praticados por cada subsidiária dos canais abertos, sobretudo no tocante à programação local. Deste modo, os cálculos não levaram em consideração tais diferenças de preços, classificados por localidade e pela distribuição dos horários entre programações locais e nacionais.

8 Agradecemos as contribuições da especialista em mídia, Cláudia Lula Mariano, pelo acesso aos preços praticados pelo mercado midiático e pelo auxílio nos cálculos e explicações quanto ao manuseio dos números.

9 A queda reportada em várias matérias sobre o assunto gira em torno de 20-30\%. http://www.jornalimpactoonline.com.br/ brasil/audiencia-cai-no-inicio-do-horario-eleitoral-gratuito-na-tv

10 Outra forma de calcular o valor do HG é levar em conta os benefícios tributários cedidos às emissoras para compensar as perdas econômicas em função do HG. Este caminho foi explorado no trabalho de Campos (2009). 
ciclo eleitoral completo de 2010 a 2013, incluindo eleições para todos os cargos nos três âmbitos federativos e o tempo cedido aos partidos nos períodos não eleitorais. A definição detalhada e uniforme dos horários de veiculação pela legislação eleitoral ${ }^{11}$ e partidária'12 facilita o cálculo do valor comercial do espaço cedido.

Começamos com o cálculo do valor comercial do chamado horário eleitoral (HGE). Para os programas em blocos, as emissoras de radiodifusão são obrigadas a destinar seis semanas, de segunda a sábado, e uma semana, de segunda à sexta, o que significa dizer que a contagem dos dias é feita até três dias antes da realização das eleições. Em termos do prazo efetivo dos programas eleitorais do HG, o mesmo corresponde a 39 dias de veiculação nas emissoras de radiodifusão (considerando apenas o primeiro turno). Para as eleições gerais, o tempo total de exibição da propaganda eleitoral é de 3.900 minutos durante todo o período. O primeiro bloco é veiculado no início da tarde (das 13h às 13h50) e o segundo em horário nobre (das $20 \mathrm{~h} 30$ às 21h20). Já para as eleições municipais, o tempo destinado à propaganda eleitoral é de 2.340 minutos para a exibição em blocos, não consideradas as inserções ao longo do HGE. Simultaneamente são veiculadas as inserções ao longo das programações normais das emissoras, com horários definidos de veiculação: os chamados spots ${ }^{13}$ de até 60 segundos. Nesse caso, não existem exceções quanto aos dias para veiculação. As inserções acontecem inclusive aos domingos e durante os 45 dias que antecedem as eleições. Esse mecanismo serve como forma adicional de o eleitor tomar conhecimento do processo eleitoral. Isso porque, considerando apenas os blocos de transmissão do HG, poderia haver uma redução na audiência, pelo fato de o eleitor comumente desligar o aparelho (Campos, 2009). As inserções curtas ao longo da programação normal da emissora reduzem (ou anulam) os efeitos desta perda de audiência. Por serem exibidos nos intervalos das programações, os spots alcançam um número maior de espectadores.

11 Lei ํㅜ 9.504, de 30 de setembro de 1997, artigos 36-41A.

12 Lei ํo 9.096, de 19 de setembro de 1995, artigos 45-49.

13 Esse formato se assemelha ao adotado para as campanhas norte-americanas ao longo da década de 1960, porém, sendo permitida a compra de espaços maiores pelos candidatos (Figueiredo et al, 1998). A adoção de spots nas eleições brasileiras se deu com a Lei no 9.100, de 1995 (Mendes, 2000). 
Tabela 2: Estimativa do valor do HG a partir dos preços praticados pelas emissoras de TV

\begin{tabular}{|c|c|c|c|c|c|c|}
\hline \multirow{2}{*}{\multicolumn{2}{|c|}{$\begin{array}{l}\text { Horário Gratuito } \\
\text { tempo/min. }\end{array}$}} & \multicolumn{2}{|c|}{ Primeiro Turno } & \multicolumn{2}{|c|}{ Segundo Turno } & \multirow[t]{2}{*}{ TOTAL } \\
\hline & & $\begin{array}{l}\text { R\$ } \\
\text { (nov./2010) }\end{array}$ & tempo/min. & $\begin{array}{l}\text { R\$ } \\
\text { (nov./2010) }\end{array}$ & $\mathrm{R} \$$ (nov./2010) & \\
\hline HG-P & $\begin{array}{l}\text { Propaganda } \\
\text { Partidária } \\
\text { (primeiro } \\
\text { semestre 2010) }\end{array}$ & 1.286 & 1.613 .123 .666 & $* * *$ & $* * *$ & 1.613.123.666 \\
\hline HG-E & $\begin{array}{l}\text { Eleições Gerais } \\
2010 \text { (em blocos) }\end{array}$ & 3.900 & 6.229 .988 .503 & 560 & 938.948 .646 & 7.168.937.149 \\
\hline HG-E & $\begin{array}{l}\text { Eleições Gerais } \\
2010 \text { (em spots) }\end{array}$ & 1.350 & 1.580.597.708 & 420 & 450.193 .063 & 2.030.790.771 \\
\hline HG-P & $\begin{array}{l}\text { Propaganda } \\
\text { Partidária (dois } \\
\text { semestres 2011) }\end{array}$ & 2.572 & 3.226.247.332 & $* * *$ & $* * *$ & 3.226.247.332 \\
\hline HG-P & $\begin{array}{l}\text { Propaganda } \\
\text { Partidária } \\
\text { (primeiro } \\
\text { semestre 2012) }\end{array}$ & 1.286 & 1.613 .123 .666 & $* * *$ & $* * *$ & 1.613 .123 .666 \\
\hline HG-E & $\begin{array}{l}\text { Eleições } \\
\text { Municipais } 2012 \\
\text { (em blocos) }\end{array}$ & 2.340 & 4.050 .889 .385 & 560 & 938.948 .646 & 4.989 .838 .031 \\
\hline HG-E & $\begin{array}{l}\text { Eleições } \\
\text { Municipais } 2012 \\
\text { (em spots) }\end{array}$ & 1.350 & 1.580.597.708 & 420 & 450.193 .063 & 2.030 .790 .771 \\
\hline HG-P & $\begin{array}{l}\text { Propaganda } \\
\text { Partidária (dois } \\
\text { semestres 2013) }\end{array}$ & 2.572 & 3.226.247.332 & $* * *$ & $* * *$ & 3.226.247.332 \\
\hline HG-E & $\begin{array}{l}\text { SOMA ciclo } 4 \\
\text { anos }\end{array}$ & 8.940 & 13.442.073.304 & 1.960 & 2.778.283.418 & 16.220 .356 .722 \\
\hline HG-P & $\begin{array}{l}\text { SOMA ciclo } 4 \\
\text { anos }\end{array}$ & 7.716 & 9.678.741.996 & $* * *$ & $* * *$ & 9.678.741.996 \\
\hline TOTAL & $\begin{array}{l}\text { Soma ciclo } 4 \\
\text { anos }\end{array}$ & 16.656 & 23.120.815.300 & $* * *$ & $* * *$ & 25.899.098.718 \\
\hline
\end{tabular}

Fonte: Adaptação de Campos (2011).

Os números da tabela 2 ilustram o valor elevado dos espaços destinados ao HG-E, durante o período da propaganda eleitoral, e demonstram a magnitude dos recursos transferidos aos partidos como forma de benefício público indireto: o equivalente do valor comercial do HG-E, durante as eleições gerais de 2010, foi de R\$ 9,2 bilhões. Ainda segundo a mesma tabela, nas eleições municipais de 2012 o valor comercial do HG-E na TV foi de R\$ 7 bilhões. A estes valores devemos acrescentar o cálculo do HG-P de TV, cedido aos partidos em períodos não eleitorais. Estes espaços estão disponíveis no primeiro semestre dos anos eleitorais e durante o primeiro e segundo semestres em anos 
não eleitorais. A tabela 2 identifica o tempo total cedido aos partidos entre 2010 e 2013 fora das campanhas eleitorais e os valores correspondentes ao espaço de propaganda. Estes somam $\mathrm{R} \$$ 9,7 bilhões para os semestres não eleitorais.

Com isto o valor comercial estimado cedido em forma de HG aos partidos e candidatos durante e fora das campanhas eleitorais soma R\$25,9 bilhões para o ciclo eleitoral 2010 a 2013. Para dimensionar a ordem de grandeza do valor comercial do horário eleitoral no conjunto de recursos mobilizados pelos partidos e candidatos na disputa política, podemos lembrar que o valor de recursos arrecadados para as campanhas eleitorais foi de R\$ 4,7 bilhões e R\$ 5,9 bilhões para as eleições de 2010 e 2012, respectivamente. Adicionalmente os partidos receberam R\$ 1,2 bilhão do Fundo Partidário para o período em questão, além dos recursos arrecadados pelos partidos em períodos não eleitorais. ${ }^{14}$ A estimativa do valor comercial do horário gratuito cedido aos partidos e candidatos em um ciclo de quatro anos (2010 a 2013) soma mais que o dobro de todos os outros recursos financeiros arrecadados por partidos e candidatos durante o mesmo período. Mesmo se tratando de um exercício hipotético que eventualmente superestima o valor comercial do horário gratuito, o cálculo do valor comercial do HG mostra a dimensão do peso desse benefício público indireto cedido a partidos e campanhas eleitorais. Ao tornar obrigatória a veiculação do HG, o Estado insere um elemento essencial para a competição partidária. O acesso à mídia eletrônica por meio do HG significa que os partidos políticos (e os candidatos) têm a seu dispor um recurso valioso quando disputam a identificação partidária dos cidadãos e os votos dos eleitores. Neste sentido o cálculo aqui apresentado corrobora e fundamenta os relatos na mídia sobre a relevância do horário eleitoral na negociação de coligações nas disputas eleitorais no Brasil. ${ }^{15}$

Nas seções anteriores, procurou-se demonstrar a importância da mídia eletrônica na disputa política entre partidos e candidatos, a partir da penetração nacional da mídia e da capacidade de levar informação a praticamente todos os domicílios do país. Depois sugerimos um método para avaliar a importância do horário gratuito a partir

14 Não há estimativas atualizadas sobre o volume de recursos arrecadados pelos partidos no âmbito nacional, estadual e municipal para todos os partidos no período de 2010 a 2013. Para estimativas referentes aos principais partidos para o período até 2009, vide Campos (2011).

15 O "preço caro" dos espaços na televisão pode ser ilustrado pelo episódio ocorrido nas eleições de 2006. O caso, amplamente divulgado pelos jornais, foi o seguinte: o candidato ao governo de Goiás pelo PSL e também presidente do partido Osvaldo Pereira, foi flagrado tentando vender o espaço de televisão do partido, que, segundo a matéria, seria de 2,10 minutos, a um "agente" por R\$ 1,3 milhão. Disponível em: http://jg.globo.com/JGlobo/0,19125,VTJ0-2742-20060828-239791,00. html. 
da precificação do espaço publicitário cedido aos partidos e candidatos. Elaboramos o nosso argumento em duas etapas. Primeiro, demonstramos o peso preponderante da TV no mercado publicitário. Depois estimamos o valor comercial do horário gratuito a partir dos preços praticados na comercialização do espaço publicitário na TV. Agora analisamos de que forma este recurso é alocado entre os partidos para verificar se a distribuição influencia a curto prazo a disputa eleitoral e a longo prazo o sistema partidário.

\section{As regras de alocação do horário gratuito entre os partidos}

A regulação da propaganda política nos meios de comunicação de massa pode ser separada em três componentes. O primeiro compreende regras que garantem acesso e isonomia de tratamento aos diferentes partidos políticos na compra de espaço publicitário. Isto tem como propósito evitar que os proprietários de meios de comunicação desequilibrem a disputa eleitoral ao vedarem a comercialização de espaço de propaganda a certos partidos ou ao praticarem preços diferentes dependendo da cor partidária. Regras deste tipo garantem equidade de acesso à propaganda paga. O segundo componente é a concessão de espaço gratuito de propaganda aos partidos e candidatos. Esta forma de subsídios é frequentemente denominada financiamento público indireto. Isso estará no centro da nossa análise. O terceiro componente se refere à regulação ou limitação da comercialização do espaço publicitário. Adotando critérios similares à regulação do financiamento privado, as regras que limitam o tempo ou conteúdo da propaganda têm o objetivo de diminuir o impacto da propaganda eleitoral nestes meios ou visam diminuir desequilíbrios no acesso ao espaço comercial devido a variações no financiamento de campanhas dos diferentes partidos. Qual é o modelo de regulação do sistema de financiamento no Brasil sob a ótica destes critérios?

O sistema de regulação do espaço publicitário para propaganda política no Brasil é de longa data e cobre os três componentes mencionados. A legislação que define os critérios para a propaganda eleitoral no Brasil é datada de 1950 e, a partir daí, as regulamentações de acesso às emissoras de rádio e TV passaram a fazer parte do arcabouço legal do país, estipulando regras para os horários de propaganda eleitoral (Rodrigues, 1981; Miguel, 1999). Muito embora não houvesse a gratuidade para partidos e candidatos, a legislação obrigava as emissoras a disponibilizarem espaços na mídia para a 
veiculação da propaganda partidária. Isso representa, portanto, uma ruptura na programação normal das emissoras de radiodifusão visando garantir o primeiro componente da regulação, a isonomia de acesso. Uma década depois o TSE lançou resolução que corroboraria o Código de 1950, cuja única menção à propaganda televisiva se limitava a considerar que as emissoras ficariam sujeitas às mesmas regras previstas para as rádios no tocante à rotatividade de tempo de veiculação entre os partidos e ao cumprimento da tabela de preços de forma igualitária. O procedimento que regulava a mídia eletrônica paga era similar ao vigente no modelo norte-americano, segundo o qual os acessos aos meios de comunicação são custeados pelos partidos e candidatos (Schmitt; Carneiro \& Kuschnir, 1999; Mendes, 2000; Jorge, 2003).

O acesso gratuito aos espaços nos meios de comunicação, pela via da propaganda eleitoral, o qual representa a entrada no segundo componente de regulação, somente foi proporcionado em 1962, dando início ao HG-E. A adoção desse procedimento se rendeu ao reconhecimento de que a comunicação seria indispensável para qualquer atividade política, que requeria meios ou veículos para se propagar. Assim, estar-se-ia estendendo as oportunidades de veiculação de propostas aos partidos como um todo, independentemente da capacidade financeira de cada partido (ou candidato). A adoção de tal critério de acesso à mídia tornaria as condições de disputa partidário-eleitoral mais equilibradas entre os concorrentes, minimizando a influência de critérios puramente econômicos (Veiga, 2001; Gomes, 2003; Miguel, 2003).

O Código Eleitoral brasileiro de 1965 estabelecia que toda propaganda eleitoral deveria ser realizada sob a responsabilidade dos partidos e por eles custeada. Contudo, não fez menção à concessão de propaganda gratuita junto aos veículos de radiodifusão, tampouco à proibição desse tipo de veiculação paga. Da mesma forma a Lei Orgânica dos Partidos Políticos (LOPP) de 1965 estabeleceu que os partidos teriam assegurado o direito de difusão e transmissão gratuita da propaganda partidária pelas empresas de radiodifusão. As emissoras ficariam obrigadas a conceder, fora dos períodos eleitorais, espaço de uma hora para os partidos apresentarem seus programas. A aprovação dessa regra, no entanto, não excluiria o uso de propaganda paga no rádio e na televisão, prevalecendo, assim, a convivência entre propaganda eleitoral gratuita e propaganda paga durante 12 anos (Campos, 2009). 
A proibição de propaganda comercial se deu apenas em 1974, chegando ao fim a propaganda política paga na televisão que, desde 1962, dividia o espaço com a propaganda gratuita. Com isto o Brasil adotou uma regra rigorosa quanto ao terceiro componente de regulação. Mais adiante, em 1976, foi outorgada a chamada "Lei Falcão"16 estipulando regras mais rígidas para a veiculação da propaganda partidário-eleitoral gratuita. A mais eminente das restrições se referia à proibição de divulgação das mensagens dos candidatos e partidos, o que atingiria, principalmente, a oposição ao regime militar (Rodrigues, 1981; Lima, 1994). Tais condições vigoraram até as eleições de 1982.

Com o término do regime autoritário, a partir de 1985 a propaganda política nos meios de radiodifusão ganhou um lugar de maior destaque no jogo político, principalmente com a disseminação dos aparelhos de televisão. Desse modo, o horário eleitoral gratuito assumiu relevância no cenário político brasileiro, transformando os veículos de comunicação de massa em instrumentos essenciais na condução do processo democrático.

Desde a Nova República, até a última eleição em 2014, ocorreram 17 eleições, com algumas variações na legislação sobre essa temática. O retorno à democracia ressaltou a importância dos veículos de comunicação para o sistema partidário-eleitoral que, de certa forma, alterou o comportamento dos partidos, dos candidatos, dos políticos eleitos e dos eleitores. Tal concepção contribuiu para a criação de regras mais rígidas para as programações e os noticiários das rádios e das televisões. A finalidade destas regras foi conter possíveis investidas dos veículos de comunicação para influenciar o processo eleitoral, garantindo a sua neutralidade durante o período da disputa eleitoral. Os critérios de alocação praticados no Brasil seriam realmente neutros em relação aos partidos que disputam a atenção de cidadãos ou eleitores?

Os critérios de distribuição dos espaços na mídia de radiodifusão foram definidos em duas legislações específicas: a Lei no 9.096, de 1995, que introduz a propaganda partidária gratuita, e a Lei oㅡ 9.504, de 1997, que estabeleceu regras permanentes para a propaganda eleitoral. ${ }^{17}$ Tratam-se de regras específicas para cada tipo de propaganda,

16 Ver Lei no 6.339, de 1976, que ficou assim conhecida pelo seu autor, o então Ministro da Justiça, Armando Falcão, que limitou a propaganda eleitoral na televisão e no rádio à veiculação exclusiva da foto e do currículo dos candidatos e número de registro na Justiça Eleitoral, sendo proibidos quaisquer outros tipos de propagandas.

17 Enquanto a propaganda eleitoral gratuita tem uma longa tradição no Brasil, o horário gratuito fora da campanha eleitoral foi introduzido somente com a legislação de 1995. 
com condições, critérios e desdobramentos distintos. Em seguida revisaremos em detaIhe a evolução da distribuição do horário gratuito de propaganda política.

A primeira característica do HG tanto durante as campanhas como fora delas é que a alocação dos recursos públicos para a competição política é fixada em lei, não sujeita a cortes ou manipulações por parte do governo ou das emissoras de rádio e TV. A segunda observação importante é que os recursos públicos, tanto diretos como indiretos, são alocados exclusivamente aos partidos políticos (e não aos candidatos). São as organizações partidárias que decidem sobre a alocação dos recursos entre os vários competidores, desde que a legislação não estabeleça regras específicas. ${ }^{18}$ Para além do monopólio de apresentar candidatos para a disputa de eleições populares, a legislação eleitoral no Brasil também garante aos partidos o monopólio sobre o acesso ao HG (e aos recursos do Fundo Partidário).

O nosso interesse principal está voltado para a questão da distribuição dos recursos entre os partidos. Se os atores financiados são os partidos e os critérios de alocação são fixados em lei, quais são estes critérios e como influenciam a competição entre os partidos?

Enfatizamos duas características. O primeiro ponto importante é que a distribuição do tempo de HG obedece a uma mescla entre critérios proporcionais e critérios equitativos. Analisaremos em detalhe estes critérios de distribuição do tempo de propaganda entre os partidos durante (HG-E) e fora das eleições (HG-P) e o impacto esperado sobre partidos pequenos, médios e grandes. O segundo ponto se refere ao critério de proporcionalidade do horário eleitoral (HG-E). Argumentamos que a vinculação da distribuição do HG-E às eleições para a Câmara dos Deputados (não levando em conta outros pleitos ou outros critérios $^{19}$ ), em combinação com a validade destes mesmos critérios para todas as eleições (prefeito, vereador, governador, deputado estadual, presidente, senador), influencia as disputas partidárias e o sistema partidário no Brasil de forma específica.

Há diferenças significativas entre os recursos alocados aos partidos durante as campanhas e em períodos não eleitorais. A propaganda partidária (HG-P) acontece todos os anos e é distribuída a cada semestre, exceto no segundo semestre de anos eleitorais,

18 Em relação à divisão do tempo entre candidatos a vários cargos, a legislação estabelece regras rígidas, deixando pouca margem de manobra aos partidos. Em relação à distribuição do espaço entre os diferentes candidatos que concorrem ao mesmo cargo (eleições proporcionais), os partidos podem priorizar determinados candidatos em detrimento de outros.

19 Para uma apresentação de diferentes critérios de alocação de recursos públicos a partidos e candidatos, vide SPECK \& DOLANDELI 2012, p. 19-27. 
quando entra em vigor a propaganda eleitoral. Os formatos de distribuição do HG-P seguem as definições próprias estabelecidas pela legislação. A distribuiçãa dos recursos do HG-P é escalonada, a partir de três grupos distintos que tomam como referência os artigos 48, 49 e 57 da Lei no 9.096, de 1995. No primeiro grupo estão todos os partidos registrados junto à justiça eleitoral. Estes têm assegurado um tempo de propaganda gratuita de 2 minutos por semestre, em blocos nacionais. No segundo grupo estão os partidos que tiveram 1\% dos votos para a CD e cumpriram outros requisitos. Estes receberam 50 minutos de HG-P por semestre, distribuídos em blocos nacionais e inserções nacionais e estaduais. Finalmente, no terceiro grupo estão os partidos que tiveram 5\% dos votos para a CD e cumpriram outros requisitos. Estes recebem 120 minutos em HG-P por semestre, também distribuídos em blocos nacionais e estaduais, e inserções nacionais e estaduais. Na propaganda partidária apenas é permitida a divulgação dos programas e das ideologias partidárias, por parte dos partidos políticos e sob a responsabilidade dos órgãos de direção partidária.

Enquanto a alocação de tempo para a propaganda partidária fora da campanha eleitoral foi introduzida somente em 1995, com a nova lei de partidos políticos, o horário para a propaganda eleitoral tem uma tradição que remonta os anos 1960. Cabe aqui uma breve retrospectiva sobre as mudanças ocorridas antes da lei eleitoral de 1997 que definiu o formato atual do horário eleitoral. De 1985 até 1996, foram editadas nove regras distintas de veiculação da propaganda eleitoral. ${ }^{20}$ Neste período ocorreram modificações em relação ao tempo total de propaganda gratuita alocada às eleições (número de dias e horas por dia), aos critérios de distribuição e à alocação de recursos entre os diferentes partidos (quadro 1). Nas eleições nacionais um terço do tempo total foi distribuído igualmente entre todos os competidores, com exceção apenas em 1994, quando este valor subiu para 41\%. Nas eleições municipais houve oscilações maiores na distribuição dos recursos. No período considerado entre 5,6 e 50\% do tempo de propaganda gratuita foi alocado de forma igualitária. A partir da lei eleitoral de 1997, a proporção de recursos distribuídos igualmente entre os candidatos foi fixada em um terço para todos os pleitos. Em relação ao critério para a alocação do tempo proporcional houve igualmente mudanças. Nas eleições anteriores, reguladas por leis eleitorais

20 Nesta contagem são consideradas apenas as leis que instituem cada processo eleitoral. Considerando as resoluções e as instruções normativas emitidas a cada eleição (para primeiro e segundo turnos), o número de legislações se eleva. Nesta retrospectiva são consideradas apenas as leis que instituem cada processo eleitoral. 
específicas, os critérios para definir a parte do horário eleitoral distribuído em função do desempenho anterior dos partidos variavam. Em algumas eleições o desempenho no âmbito municipal e estadual entrou no cálculo da proporcionalidade, enquanto em outras o critério foi unicamente o desempenho no âmbito nacional. Com a lei eleitoral de 1997, a distribuição das cadeiras na Câmara dos Deputados foi fixada como sendo o único critério para todas as eleições. A partir de 1997 as regras de condução do horário eleitoral gratuito, em rádio e em televisão, permaneceram praticamente inalteradas. ${ }^{21}$

Quadro 1: Regras do HGPE para períodos eleitorais (desde 1985 - atual)

\begin{tabular}{|c|c|c|c|c|c|c|c|c|c|}
\hline Legislação & $\begin{array}{l}\text { Lei } \\
7.332, \\
\text { de } 1985\end{array}$ & $\begin{array}{l}\text { Lei } \\
7.508, \text { de } \\
1986\end{array}$ & $\begin{array}{l}\text { Lei } 7.664 \text {, } \\
\text { de } 1988\end{array}$ & $\begin{array}{l}\text { Lei } \\
7.773, \\
\text { de } \\
1989 \\
\end{array}$ & $\begin{array}{l}\text { Resolução } \\
16.402 \text {, de } \\
1990\end{array}$ & $\begin{array}{l}\text { Lei } \\
8.214, \\
\text { de } 1991\end{array}$ & $\begin{array}{l}\text { Lei } \\
8.713, \\
\text { de } 1993\end{array}$ & $\begin{array}{l}\text { Lei } \\
9.100, \\
\text { de } 1995\end{array}$ & $\begin{array}{l}\text { Lei } \\
9.504, \\
\text { de } 1997\end{array}$ \\
\hline $\begin{array}{l}\text { Aplicada às } \\
\text { eleições de: }\end{array}$ & $\begin{array}{c}1985 \\
\text { Munic. }\end{array}$ & 1986 & $\begin{array}{c}1988 \\
\text { Munic. }\end{array}$ & 1989 & 1990 & $\begin{array}{c}1992 \\
\text { Munic. }\end{array}$ & 1994 & $\begin{array}{c}1996 \\
\text { Munic. }\end{array}$ & $\begin{array}{c}1998 \text { e } \\
\text { Posterior }\end{array}$ \\
\hline $\begin{array}{l}\text { Dias de } \\
\text { propagan- } \\
\text { da eleitoral }\end{array}$ & 60 & 60 & 45 & 60 & 60 & 45 & 60 & 60 & 45 \\
\hline $\begin{array}{l}\text { Minutos } \\
\text { por dia }\end{array}$ & 60 & 120 & 90 & 120 & 120 & 80 & 120 & 60 & $\begin{array}{c}(100 \\
\text { gerais) } \\
(60 \\
\text { munic.) }\end{array}$ \\
\hline $\begin{array}{l}\text { Dis- } \\
\text { tribuição } \\
\text { equitativa }\end{array}$ & $50 \%$ & $33,3 \%$ & $5,6 \%$ & $3,1 \%$ & $33,3 \%$ & $25 \%$ & $41,7 \%$ & $20 \%$ & $33,3 \%$ \\
\hline $\begin{array}{l}\text { Dis- } \\
\text { tribuição } \\
\text { proporcio- } \\
\text { nal }\end{array}$ & $50 \%$ & $66,7 \%$ & $94,4 \%$ & $96,9 \%$ & $66,7 \%$ & $75 \%$ & $58,3 \%$ & $80 \%$ & $66,7 \%$ \\
\hline $\begin{array}{l}\text { Critério } \\
\text { proporcio- } \\
\text { nalidade }\end{array}$ & $\begin{array}{c}\text { Pro- } \\
\text { porção } \\
\text { bancadas } \\
\text { na CV }\end{array}$ & $\begin{array}{c}\text { Pro- } \\
\text { porção } \\
\text { bancadas } \\
\text { da CD/ } \\
\text { ALs }\end{array}$ & $\begin{array}{c}\text { Proporção } \\
\text { na CD/ } \\
\text { ALs }\end{array}$ & $\begin{array}{c}\text { Pro- } \\
\text { porção } \\
\text { na CD }\end{array}$ & $\begin{array}{l}\text { Proporção } \\
\text { bancadas } \\
\text { da CD/ALs }\end{array}$ & $\begin{array}{c}\text { Pro- } \\
\text { porção } \\
\text { na CD/ } \\
\text { ALs }\end{array}$ & $\begin{array}{c}\text { Pro- } \\
\text { porção } \\
\text { na CD }\end{array}$ & $\begin{array}{c}\text { Pro- } \\
\text { porção } \\
\text { na CD }\end{array}$ & $\begin{array}{c}\text { Pro- } \\
\text { porção } \\
\text { na CD }\end{array}$ \\
\hline
\end{tabular}

Fonte: Speck \& Campos, 2011.

21 A lei eleitoral de 1997 previa a entrada em vigor de novas regras de distribuição do horário eleitoral após o pleito de 2006. No entanto, o STF, em 2006, após os resultados das eleições, derrubou a chamada "cláusula de barreira". A votação se deu a favor de Ação Direta de Inconstitucionalidade (ADIN) contra o artigo 13 da Lei no 9.096, de 1995, que entraria em vigor nas eleições gerais de 2006. Como resultado o conteúdo das regras de alocação do horário eleitoral continuou inalterado. 


\section{O impacto da distribuição do HG entre partidos sobre a frag- mentação partidária}

Como a distribuição do tempo influenciou a disputa eleitoral entre os partidos? Esta questão está no centro da nossa análise. O primeiro argumento deste artigo é que a distribuição do horário de propaganda partidária e da propaganda eleitoral contribui para a alta fragmentação partidária no Brasil. Partimos do pressuposto de que a alocação do tempo de propaganda na TV seguindo estritamente o critério da proporcionalidade em relação ao sucesso eleitoral no passado consolidaria a posição de cada partido. Um partido que recebeu 10\% dos votos na eleição passada e que conta com 10\% do tempo do horário eleitoral gratuito no próximo pleito não teria as suas chances de sucesso distorcidas pelo horário eleitoral. Neste modelo a proporcionalidade é interpretada como "não distorção".22 Por outro lado, partidos que recebem mais tempo do que o número de votos que tiveram no passado teriam chance de aumentar a sua presença no próximo pleito, enquanto partidos que recebem proporcionalmente menos tempo tenderiam a encolher. No nosso modelo estas duas situações são interpretadas como distorção. O gráfico 2 reproduz o quanto a alocação do horário gratuito distorce as chances dos partidos nas disputas entre partidos fora das campanhas eleitorais. $\bigcirc$ gráfico 3 analisa a mesma questão para disputas entre partidos nas campanhas eleitorais. Ambos os gráficos têm no eixo $x$ a proporção de votos obtidos pelos partidos na última eleição apara a Câmara dos Deputados. O eixo y representa a participação de cada partido no tempo de propaganda partidária (gráfico 2) e no tempo de propaganda eleitoral (gráfico 3). 0 critério de distribuição proporcional do tempo que corresponde à alocação sem distorção é representado pela linha diagonal interrompida. Caso o tempo fosse distribuído estritamente de forma proporcional ao sucesso eleitoral, os marcadores do horário de cada partido deveriam estar exatamente nesta linha diagonal. Os pontos acima da linha significam que estes partidos receberam mais tempo do que Ihes corresponderia pelo critério proporcional. Os pontos abaixo da linha significam que estes partidos receberam menos tempo do que lhes corresponderia se a distribuição fosse proporcional.

22 É inegável que o modelo tem um fundo normativo. Considerar a proporcionalidade da distribuição como ausência de distorção é uma decisão normativa, a favor do continuísmo como normalidade. Uma alternativa seria partir do pressuposto de que chances iguais para cada partido representam ausência de distorção. Neste caso a distribuição atual do tempo deveria ser comparada a uma linha horizontal de alocação no gráfico 4. 
Examinando o gráfico 2 a respeito da distribuição do horário eleitoral (HG-P) entre os diferentes partidos nos períodos não eleitorais entre 2011 e 2014, verificamos que, comparada com a votação para a Câmara dos Deputados em 2010 a distribuição do horário para a propaganda partidária favoreceu os partidos médios e prejudicou os partidos pequenos e os grandes. O gráfico 2 ilustra a distorção da distribuição dos recursos. Tomando como referência o critério da proporcionalidade em relação aos votos obtidos na eleição para a CD, indicado pela linha diagonal interrompida, verificamos que os dois minutos recebidos pelos partidos pequenos ficaram abaixo da proporção de votos conquistados por estes partidos na eleição para a Câmara dos Deputados em 2010. Por exemplo, o PSOL obteve 0,6\% dos votos para a Câmara dos Deputados e somente dois minutos do horário semestral, correspondendo a 0,16\% do total do tempo concedido a todos os partidos. No segundo grupo dos partidos de tamanho médio a situação se inverteu. Para a maioria dos partidos que conquistaram entre 2\% e 10\% dos votos na eleição de 2010, o tempo de propaganda partidária gratuita concedida está acima da proporção de votos obtidos. Por exemplo, o PDT obteve 5\% dos votos e 5,3\% das cadeiras, mas recebeu 9,3\% do tempo de propaganda partidária. No terceiro grupo dos partidos que conseguiram acima de 10\% dos votos nas eleições de 2010, o tempo de propaganda partidária ficou novamente abaixo da alocação proporcional. O PT, que obteve $16,8 \%$ dos votos, recebeu 9,3\% do tempo de propaganda partidária nos semestres sem eleição para os próximos quatro anos. Em resumo, o sistema de alocação de tempo para a propaganda partidária em períodos não eleitorais, que cria três faixas diferentes de acesso, tende a desfavorecer os partidos nanicos até $2 \%$ dos votos, favorece os partidos médios até 10\% dos votos e novamente desfavorece os partidos grandes, acima de 10\%. Esta relação é representada pela linha de tendência vermelha no gráfico 2. 
Gráfico 2: Votos, tempo de propaganda partidária e proporcionalidade $(2010 / 2011)$

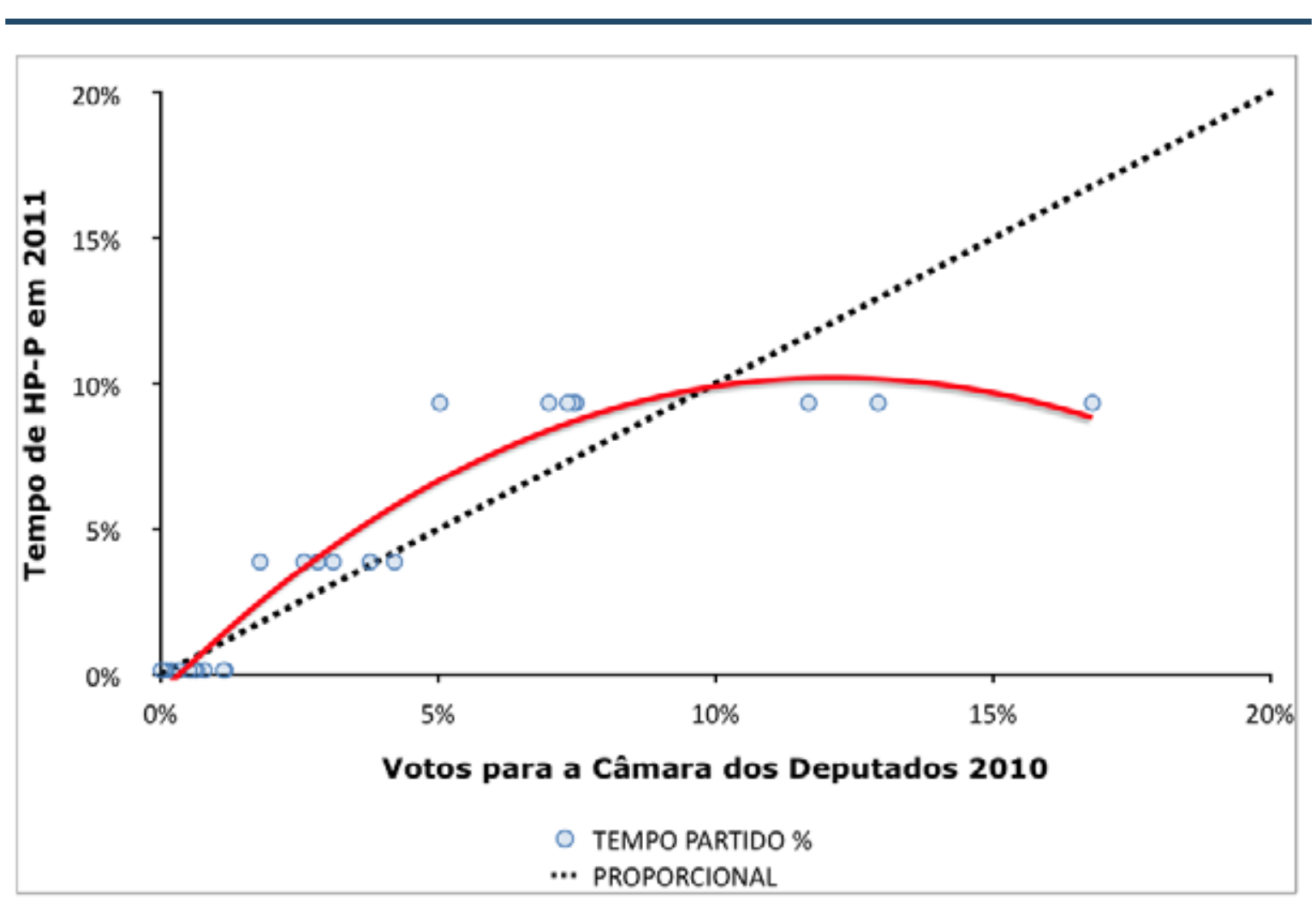

No caso do horário eleitoral (HG-E) o padrão da distorção é diferente. Como visualizado no gráfico 3, agora os partidos pequenos levam vantagem na distribuição do tempo de propaganda e os partidos grandes são prejudicados. O gráfico ilustra que a desproporção é quase linear, representada novamente pela linha vermelha de tendência. Os partidos que têm uma votação de até aproximadamente 4\% dos votos para a Câmara dos Deputados recebem uma parcela do tempo de propaganda eleitoral acima da sua votação. Por exemplo, o PCO, que recebeu $0,01 \%$ dos votos nas eleições para a Câmara dos Deputados. Como não elegeu nenhum representante, teve direito somente à distribuição equitativa de um terço do tempo de propaganda eleitoral distribuída entre todos os partidos, correspondendo a 1,2\% do tempo de propaganda. Da mesma forma o PSOL, com os já citados 0,6\% de votos para a Câmara dos Deputados, teve direito a 2,5\% do tempo do horário eleitoral nas eleições de 2012. Estes partidos foram beneficiados pelo sistema de alocação de recursos, tomando como referência a meta da proporcionalidade. Na medida em que os partidos superam esta marca dos $4 \%$ de 
votos, a sua participação no horário eleitoral fica aquém da proporção de votos. Por exemplo, o PSB recebeu 6,8\% dos votos, mas teve direito a somente 5,3\% do tempo do horário eleitoral nas próximas eleições. Os maiores partidos (PT, PSDB, PMDB) sofrem o maior efeito deste desfavorecimento pelo sistema de distribuição do tempo do horário eleitoral. Por exemplo, o PT recebeu 16,8\% dos votos para a Câmara dos Deputados em 2010, mas teve direito a somente 9,7\% do tempo do horário eleitoral nas próximas eleições. Resumindo, o sistema de distribuição do tempo da propaganda eleitoral favorece partidos que tiveram uma participação abaixo de 4\% dos votos na eleição para a Câmara dos Deputados e desfavorece os partidos que tiveram um desempenho acima desta marca. A distorção se acentua quanto mais distante os partidos estiverem desta marca. ${ }^{23}$

Gráfico 3: Votos, tempo de propaganda eleitoral e proporcionalidade (2010/2012)

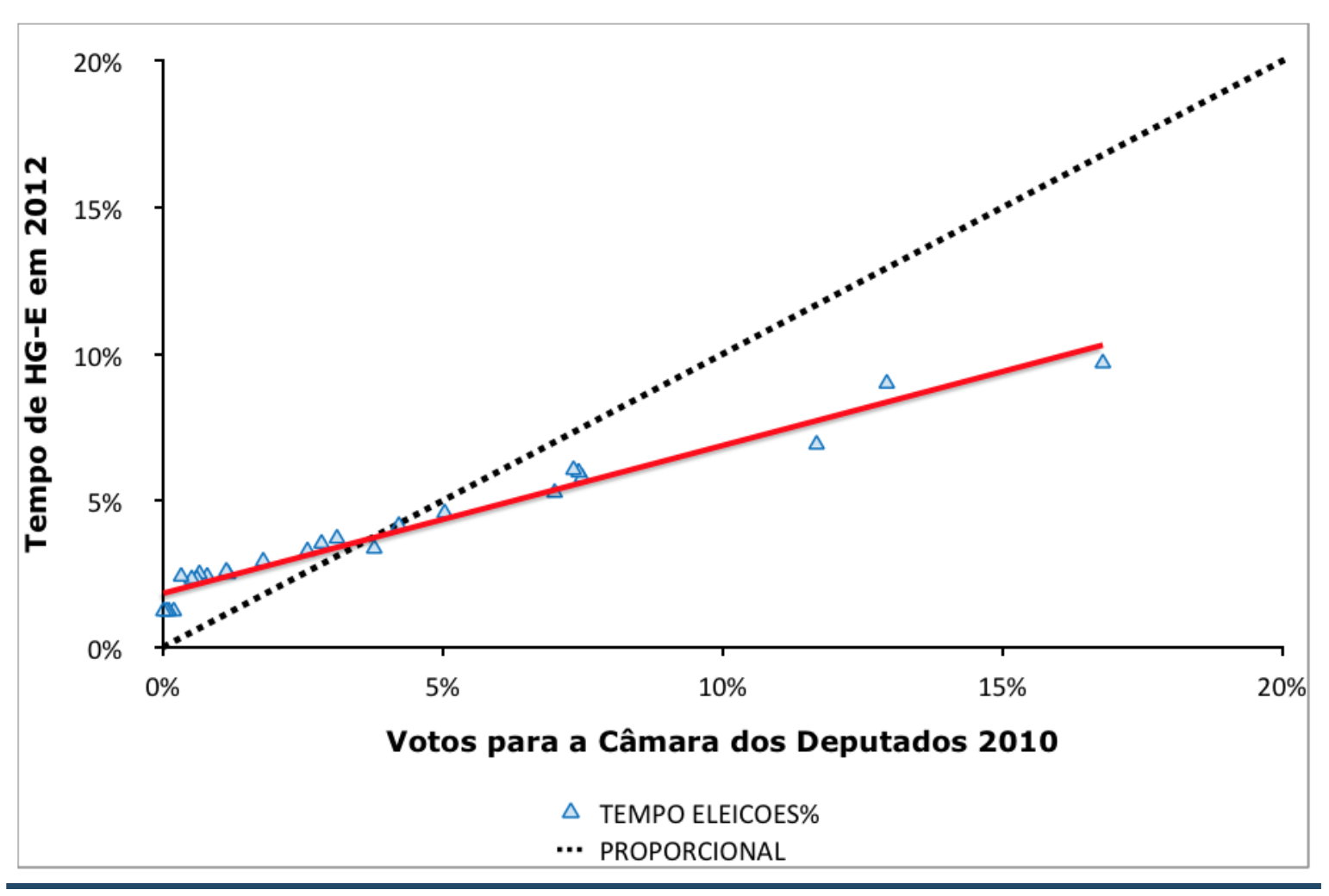

23 Uma vez que a alocação do tempo do horário eleitoral leva em conta as cadeiras na Câmara dos Deputados e não os votos na eleição, não há uma correspondência exata deste "ponto de virada" nos votos conquistados. 


\section{O impacto da alocação uniforme e universal do HG sobre a nacionalização dos partidos}

Uma outra característica da distribuição de tempo da propaganda gratuita tem também impacto sobre o sistema partidário. Para explicitar o argumento, trataremos do HG-E na campanha eleitoral, mas o tal argumento se aplica da mesma forma ao impacto do HG-P. Nos referimos à combinação de duas técnicas para definir a distribuição de tempo de propaganda gratuita entre partidos políticos. Primeiro, a alocação dos recursos proporcionais ocorre em função de um único pleito, a eleição para a Câmara dos Deputados; segundo, este critério de alocação é adotado para definir o tempo do horário gratuito em todas as circunscrições (no caso do HG-P e HG-E) e em todos os pleitos (no caso do HG-E) nos próximos quatro anos. Chamaremos o primeiro elemento (a definição do tempo em função da eleição na Câmara dos Deputados) de uniformização e o segundo elemento (eleições para todos os cargos em todas as circunscrições) de universalização. A nossa hipótese é que a uniformização e a universalização criam fortes incentivos para a nacionalização do sistema partidário. ${ }^{24}$

A definição da distribuição proporcional dos recursos em função de uma única eleição (cadeiras na Câmara dos Deputados) cria um forte incentivo para que os partidos priorizem as disputas para este cargo. Principalmente para os partidos nanicos e pequenos, é extremamente importante lançar candidatos na eleição para deputados no âmbito nacional a fim de maximizar o horário eleitoral. Não há tempo a perder com a criação e consolidação de bases locais para formar quadros no âmbito municipal, para depois se afirmar no âmbito estadual. Um partido construído a partir de raízes locais não sobreviveria nas próximas eleições, pois somente participaria de uma pequena fração (a parte distribuída igualmente) do HG-E. Os critérios de distribuição do horário eleitoral citados impedem partidos de firmarem-se de baixo para cima, começando no âmbito municipal, consolidando-se na política estadual em determinadas regiões para finalmente disputar cargos no âmbito nacional. A pressão é pela priorização imediata das eleições para a Câmara dos Deputados.

24 Para demonstrar que as duas técnicas (de definição e de alocação de tempo) poderiam ocorrer separadamente, podemos imaginar sistemas que a) substituem o critério único (composição da CD) pela combinação de vários critérios de desempenho para definir a distribuição proporcional do tempo ou que b) substituem a aplicação universal do critério por um sistema que vincula cada eleição ou circunscrição ao desempenho passado. 
A importância da Câmara dos Deputados para a definição do HG também teve reflexo na questão da migração partidária. A literatura na ciência política sobre a migração partidária dos candidatos eleitos detectou altas taxas de mudança de partido entre os deputados imediatamente antes da data limite para definir o horário eleitoral para o próximo pleito. Até 2006 a legislação previa que a composição da Câmara dos Deputados no início do ano eleitoral seria usada para o cálculo da alocação proporcional do tempo de propaganda, criando desta forma incentivos para os partidos aumentarem as suas bancadas antes da data limite. Duas reformas atenuaram ou anularam estes incentivos. Em primeiro lugar, em 2006 a minirreforma eleitoral definiu que a composição da Câmara dos Deputados no momento da posse dos eleitos serviria como critério para a alocação do tempo de propaganda. ${ }^{25}$ Eventuais trocas de partido após esta data seriam desconsideradas para fins de distribuição do horário eleitoral nos pleitos seguintes. Em segundo lugar, a resolução do TSE em 2007 de atribuir os mandatos aos partidos criou mais uma barreira para migração e para os fins do horário eleitoral, anulando a possibilidade de migração entre a eleição e a posse dos eleitos. Com estas duas modificações, o atalho de garantir a representação na CD por meio de migração partidária, sem passar pelo crivo das eleições, foi praticamente fechado.

Os incentivos acima descritos se referem à centralidade da composição da Câmara dos Deputados para a distribuição do horário eleitoral, estimulando a prioridade da disputa para a Câmara dos Deputados e a migração partidária dos deputados federais eleitos. Outro aspecto importante é a alocação universal do tempo de propaganda em todas as eleições e em todas as circunscrições durante quatro anos, segundo este critério. Argumentamos que a rápida expansão de partidos novos para disputar eleições em todas as unidades da federação, observada primeiro em relação às disputas estaduais e depois também nas disputas municipais, descrita em vários trabalhos sobre o sistema partidário (Braga, 2006; Campos, 2011), tem uma das suas razões nesta fórmula de acesso a um recurso essencial de campanha, o HG, combinando uniformidade com universalização.

Argumentamos que a alocação de tempo de horário eleitoral igual em todas as eleições no âmbito nacional, estadual e municipal cria fortes incentivos para a

25 A lei eleitoral no 9.504/1997 previa na sua redação original a composição da Câmara no início da legislatura. Com a reforma de Lei no 11.300/2006, o critério passou a ser a composição da Câmara após a última eleição. 
nacionalização dos partidos políticos. Partidos que tiverem direito à determinada fatia do HG-E e que não estiverem presentes em determinado município ou Estado sofrerão forte incentivo para abrir um diretório nestas circunscrições e utilizar o espaço de propaganda para promover os seus próprios candidatos ou apoiar coligações. Da mesma forma, partidos fortes no âmbito nacional, mas fracos em determinadas regiões, tenderão a crescer até chegar num ponto de equilíbrio, formado próximo da média nacional. Esta característica da alocação uniforme do HG-E é um dos motores para a rápida nacionalização do sistema partidário no Brasil. O gráfico 4 ilustra o efeito deste nivelamento sobre os partidos. O gráfico representa a votação hipotética de um partido em uma eleição em diferentes circunscrições (linha errática), indicando como a alocação uniforme do horário eleitoral (linha pontilhada), em função das cadeiras na Câmara dos Deputados, influenciará a segunda eleição (flechas).

A partir desta ilustração gráfica também depreendemos que os partidos sofrem o efeito inverso nos seus redutos eleitorais com forte votação. Partidos que tiverem uma forte votação em determinada circunscrição terão dificuldades de repetir este desempenho na próxima eleição porque o seu tempo de horário eleitoral será alocado em função da mesma média nacional (cadeiras na CD), não levando em conta o desempenho local do partido. As siglas pequenas tendem a abrir diretórios e lançar candidatos nas regiões onde não são representadas, enquanto as siglas grandes sofrem o efeito do acesso desproporcionalmente menor ao HG-E em regiões ou circunscrições onde são temporariamente fortes em comparação com a sua média nacional. O efeito é uma aproximação dos partidos à sua média nacional, definida pelo horário eleitoral.

Neste sentido este estudo também dialoga com a literatura sobre a nacionalização do sistema partidário no Brasil. Vários pesquisadores apontaram para a tendência da nacionalização do sistema partidário no Brasil (Jones \& Mainwaring, 2003; Braga, 2006), associando este conceito à universalização e uniformização da presença dos partidos políticos nas disputas eleitorais em diferentes regiões no Brasil desde a volta ao multipartidarismo. Argumentamos aqui que um dos motores da nacionalização neste sentido é a forma de definição e alocação do horário eleitoral gratuito entre os partidos que competem nas eleições brasileiras. Ela uniformiza o critério de definição do tempo de cada partido e universaliza a sua aplicação em todas as disputas subsequentes durante 
o quadriênio seguinte. O resultado é uma pressão pelo nivelamento do desempenho eleitoral de partidos em função da sua presença na Câmara dos Deputados.

Gráfico 4: O efeito de nivelamento do HG sobre a presença regional dos partidos

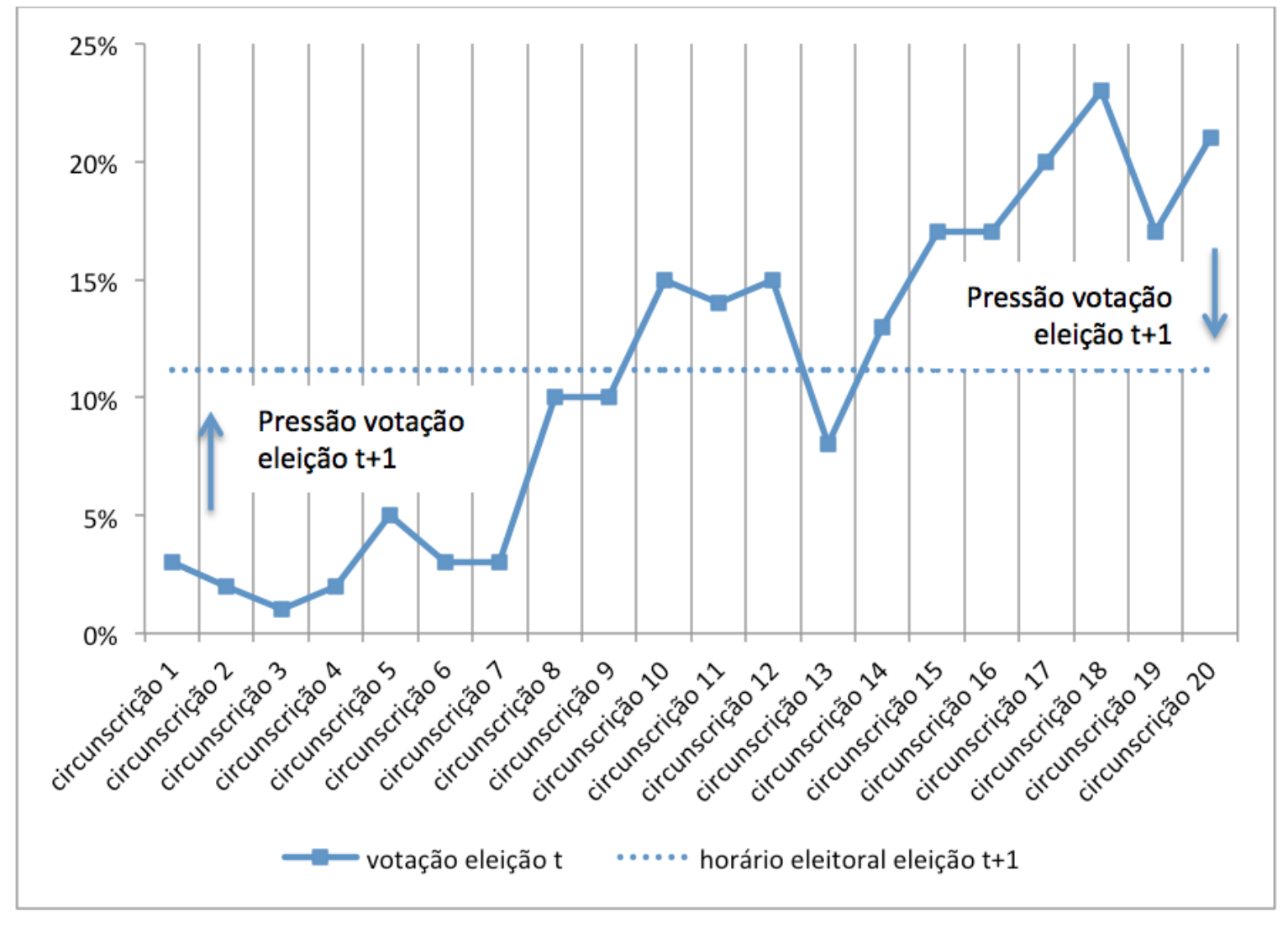

\section{Considerações finais}

O argumento do texto parte de considerações teóricas a respeito do impacto esperado do HG nas duas modalidades de propaganda, fora e durante o processo eleitoral, sobre o sistema partidário. Utilizamos dados sobre as regras de distribuição do HG desde 1995 e exemplos da distribuição de votos, cadeiras e tempo de TV para o período de 2002 a 2013. Os dados usados têm a finalidade de ilustrar os argumentos teóricos e abrir uma agenda de pesquisa para testar as hipóteses lançadas.

Na primeira parte da nossa análise, chegamos à conclusão de que o HG é um recurso relevante para a disputa eleitoral. Mesmo que os valores da precificação da propaganda partidária e da propaganda eleitoral possam ser questionados em relação aos 
valores exatos calculados, o cálculo mostra que este recurso público indireto exerce influência sobre o sistema partidário no mesmo patamar de influência dos recursos privados. A alocação destes subsídios indiretos do Estado aos partidos e às campanhas eleitorais merece mais atenção dos observadores políticos e dos cientistas políticos. Este texto é uma contribuição para este debate.

A partir desta constatação sobre a relevância do acesso gratuito e exclusivo à mídia de radiodifusão no Brasil, analisamos as regras para a alocação e distribuição do HG aos diferentes partidos. Constatamos que a propaganda eleitoral, pelos seus elementos de distribuição igualitária, beneficia as legendas nanicas e pequenas do quadro partidário brasileiro. Estes recebem acesso ao HG proporcionalmente acima da sua participação nas eleições para a CD. No caso da propaganda partidária, em período não eleitoral, o quadro é mesclado. Os partidos nanicos são prejudicados enquanto os partidos pequenos são privilegiados. Para os maiores partidos o efeito do horário gratuito é mais claro. Tanto na propaganda eleitoral como na propaganda partidária eles recebem proporcionalmente menos tempo no HG em comparação com o seu peso na eleição para a CD. Neste sentido, a análise do efeito do HG-E sobre a disputa eleitoral no Brasil dialoga com a tese de Katz e Mair (1995) sobre a cartelização do sistema partidário. A nossa análise lança sérias dúvidas sobre esta tese da "cartelização" partidária para o caso brasileiro, propondo no seu lugar a tese do "teto de crescimento" para partidos grandes embutido no modelo brasileiro de alocação do tempo gratuito.

Por outro lado, identificamos que a regra de vincular o tempo proporcional do HG às eleições para a CD exerce duas influências importantes sobre o sistema partidário. Ela obriga as legendas pequenas a priorizarem as eleições para a CD, antes de consolidar as bases locais ou regionais. O segundo efeito é a nacionalização do sistema partidário. Uma vez que a distribuição do HG-E é uniforme em todas as circunscrições, este recurso público indireto alocado aos partidos exerce forte pressão para a apresentação de candidaturas onde o partido não estiver presente ou onde tiver presença eleitoral fraca. Por outro lado, partidos que tiverem um desempenho eleitoral forte em determinada região ou circunscrição sofrerão pressão eleitoral dos seus concorrentes porque estes terão acesso desproporcional ao recurso do horário eleitoral. Os efeitos mais relevantes do HG não estão vinculados à cartelização do sistema partidário, mas à fragmentação e nacionalização dos partidos brasileiros. 
Os argumentos aqui levantados sobre a relação entre os subsídios públicos e o sistema partidário estão longe de esgotar o assunto. Mostramos que este recurso precisa ser inserido nas análises sobre a relação entre recursos e sucesso eleitoral. Enquanto a memória eleitoral, seja do voto partidário, seja do voto personalista, tende a reproduzir os resultados do passado em cada circunscrição, a influência do HG favorece partidos pequenos e leva ao nivelamento da força dos partidos pela média nacional. Estudos empíricos serão necessários para apoiar ou refutar as hipóteses aqui lançadas.

\section{Bibliografia}

ALBUQUERQUE, A. de \& DIAS, M. R. Propaganda Política e a Construção da Imagem Partidária no Brasil: Considerações Preliminares. In: Civitas - Revista de Ciências Sociais, v. 2, no 2. Porto Alegre, dezembro 2002.

ALVES, José Eustaquio Diniz Alves. As características dos domicílios brasileiros entre 1960 e 2000. Ministério do Planejamento, Orçamento e Gestão, Instituto Brasileiro de Geografia e Estatística - IBGE, Escola Nacional de Ciências Estatísticas. Textos para discussão número 10, 2004.

ANSOLABEHERE, S.; GERBER, A. S. \& SNYDER JR., J. M. Corruption and Growth of Campaign Spending. Edited by Gerald C. Lubenow. A User's Guide to Campaign Finance Reform. Ed. Rowman \& Littlefield, 2001.

AZEVEDO, F. A. Mídia e democracia no Brasil: relações entre o sistema de mídia e o sistema político. In: Opinião Pública, Campinas, v. 12, no 1, abril/maio 2006, p. 88-113.

BORBA, F. M. Razões para a escolha eleitoral: a influência da campanha política na decisão do voto em Lula durante as eleições presidenciais de 2002. Dissertação de Mestrado. Rio de Janeiro: IUPERJ, 2005.

BRAGA, M. S. S. O processo partidário-eleitoral brasileiro. Padrões de competição política (1982-2002). São Paulo, Associação Editorial Humanitas/FAPESP, 2006.

CAMPOS, M. M. Democracia, partidos e eleições: os custos do sistema partidário-eleitoral no Brasil. Belo Horizonte, tese de doutorado em Ciência Política, UFMG, 2009.

CAMPOS, M. M. O valor da mídia eletrônica para a competitividade do sistema partidárioeleitoral. In: Revista da Fundação Barão e Visconde de Mauá, p. 26-34, 2011.

DIAS, M. A mentira das urnas: crônica sobre dinheiro e fraudes nas eleições. Rio de Janeiro: 


\section{Ed. Record, 2004}

DUVERGER, M. Os partidos políticos. 2. Ed., Rio de Janeiro: Zahar, UnB, 1980.

FIGUEIREDO, M. Reforma do sistema político: representação, partidos e eleições. In: PEPPE, A. M. e LESBAUPIN, I. (orgs.). Revisão constitucional e Estado Democrático. Rio de Janeiro/ São Paulo: Centro João XXIII/Edições Loyola, 1993.

\& ALDÉ, A. Intenção de voto e propaganda política: efeitos e gramáticas da propaganda eleitoral. In: Actas do III Sopcom, VI Lusocom e II Ibérico - v. IV, 2005. Disponível em: http://bocc.ubi.pt/pag/figueiredo-alde-intencao-voto-propaganda-politica.pdf. Acessado em: 18/12/2007.

; DIAS, H. \& JORGE, V. L. Estratégias de persuasão em eleições majoritárias: uma proposta metodológica para o estudo da propaganda eleitoral. Serie Estudos IUPERJ, Rio de Janeiro, vol. 100, 1998.

GRINER, S. \& ARIAS, C. Médios de comunicación y partidos políticos em America Latina.Una aproximación mas allá de la obsesión por controlar el gasto electoral. In: El triangulo de las Bermudas. El financiamiento de la política em México, Friedrich Ebert Stiftung, México-DF, Septiembre 2007, p. 41-53.

GOMES, W. Propaganda política, ética e democracia. In: MATOS, H. (org.). Mídia, eleições e democracia. Scritta: São Paulo, 1994.

JONES, M. P. \& MAINWARING, S. The nationalization of parties and party systems: An empirical measure and application to the Americas. Party Politics, v. 9, no. 2, 2003, p. 139-166.

JORGE, V. L. Meios de comunicação de massa e Poder Legislativo. Uma análise da cobertura do Congresso Nacional pelos jornais brasileiros, 1985 a 1990. Tese de Doutorado. IUPERJ, 2003.

KATZ, R. S. \& MAIR, P. Changing models of party organization and party democracy. Party Politics. v. 1. no 1, 1995.

. The Ascendancy of the Party in Public Office: Party Organizational in TwentiethCentury Democracies. Ed. by GUNTHER, R.; RAMÓN-MONTERO, J. \& LINZ, J. Political Parties: Old Concepts and New Challenges. Oxford University Press, 2002.

LIMA, V. A. Propaganda política no rádio e na televisão. In: MATOS, Heloísa (org.). Mídia, eleições e democracia. Scritta: São Paulo, 1994.

MELO, C. R. Retirando as cadeiras do lugar: migração partidária na Câmara dos Deputados (1985-2002). Belo Horizonte: Ed. UFMG, 2004. 
MENDES, S. J. Spots Eleitorais: as restrições na eleição de 1998. In: RUBIM, Antônio A. C. (org.). Mídia e eleições de 1998. FACOM/UFBA: Salvador, 2000.

NICOLAU, J. Multipartidarismo e democracia: um estudo sobre o sistema partidário brasileiro (1985-1994). Rio de Janeiro: Ed. FGV, 1996.

PACHECO, C. Marketing eleitoral: a política apolítica. In: Revista Comunicação\&Política, n.S., v. 1, agosto/novembro 1994.

REIS, A. A dança dos números: o impacto das pesquisas eleitorais nas estratégias de comunicação do HGE nas eleições de 2000 em São Paulo. In: XXVI Congresso Brasileiro de Ciências da Comunicação. Belo Horizonte, setembro 2003. Disponível em: http:// www.intercom.org.br/papers/nacionais/2003/www/pdf/2003_NP03_reis.pdf. Acessado em: 12/16/2008.

RIAL, J. Financiamiento político: el acceso de los partidos a los medios de comunicación. In: GRINER, Steven \& ZOVATTO, Daniel (eds.). De las Normas a las Buenas Prácticas: El desafío del financiamiento político en América Latina. Publicado por la Organización de los Estados Americanos (OEA) y el Instituto Internacional para la Democracia y la Asistencia Electoral (IDEA). San José, 2004.

RODRIGUES, M. R. A. N. Eleições: vende-se um candidato. Milesi Ed.: São Paulo, 1981.

SARTORI, G. Videopolítica. In: Rivista Italiana di Scienza Política, anno XIX, no 2, p. 185-198, agosto, 1989.

SCHMITT, R.; CARNEIRO, L. P.; \& KUSCHNIR, K. Estratégias de Campanha no Horário Gratuito de Propaganda Eleitoral em Eleições Proporcionais. In: Revista Dados, v. 42, no 2, 1999.

SPECK, B.W. Reagir a escândalos ou perseguir ideais? A regulação do financiamento político no Brasil. In: HOFMEISTER, W. (org.). Reforma política: agora vai? 1. ed. Rio de Janeiro: Fundação Konrad Adenauer, 2005, v. VI, p. 123-159.

SPECK, B.W. \& CAMPOS, M. M. The Impact of State Funding On Political Parties on the National and State Level. In: International Political Science Association (IPSA). University of Sao Paulo, Brazil, February 16-19, 2011.

\& CERVI, E. U. O peso do dinheiro e do tempo de rádio e TV na disputa do voto para prefeito. Texto apresentado para o II Workshop Nacional Como o eleitor escolhe o seu prefeito. As lógicas do voto. Universidade Federal de Minas Gerais Belo Horizonte, 23 a 24 maio 2013. 
Voto, dinheiro e horário eleitoral: Uma aplicação do método "path analysis" para explicar os condicionantes da eleição para prefeito do Brasil. Texto apresentado no IX Encontro da ABCP, Brasília, 4 a 7 de agosto 2014.

\& DOLANDELI, R. A responsabilidade das empresas no processo eleitoral. Edição 2012, Instituto Ethos/Transparency International, São Paulo, setembro 2012.

SILVEIRA, B. S. \& MELLO, J. M. P. Campaign advertising and election outcomes: Quasi-natural experiment evidence from gubernatorial elections in Brazil. In: Review of Economic Studies (2011), 78, 590-612.

VEIGA, L. Em busca de razões para o voto: o uso que o homem comum faz do horário eleitoral. Tese de Doutorado. IUPERJ, 2001. Marketing político e decisão do voto: como agem os eleitores diante das Propagandas eleitorais. In: 11ํo Compós - Encontro Nacional da Associação dos Programas de PósGraduação em Comunicação. Rio de Janeiro, junho de 2002.

ZOVATTO, D. Dinero y Política en América Latina: una visión comparada. In: Cuaderno de Ciencias Sociales 130. San José, Costa Rica: Facultad Latinoamericana de Ciencias Sociales (FLACSO), mayo, 2004.

Recebido: 29/07/2014 Aceito: 6/11/2014 